\title{
Jakość życia i aktywność zawodowa pacjenta po przebytym zawale mięśnia sercowego
}

\section{Quality of life and professional activity of the patient after myocardial infarction}

\author{
MARTA KAMIŃSKA ${ }^{1}$, MARIOLA RYBKA ${ }^{2}$ \\ 1 Studenckie Koło Naukowe Nauk o Zdrowiu, Instytut Nauk o Zdrowiu PWSZ \\ we Włocławku, opiekun Koła: dr Beata Haor \\ 2 Instytut Nauk o Zdrowiu PWSZ we Włocławku \\ DOI: http://dx.doi.org/10.21784/IwP.2018.023 \\ ISSN: 2451-1846
}

\section{Streszczenie:}

Wstęp. Zawał mięśnia sercowego jest najczęściej występującym schorzeniem układu krążenia. Jest to martwica komórek mięśniowych określonego obszaru serca, która została wywołana zamknięciem światła naczynia wieńcowego, najczęściej w wyniku pęknięcia blaszki miażdżycowej. Pacjent po zawale serca musi dokonać wielu zmian związanych $\mathrm{z}$ jego dotychczasowym trybem życia. Jak najwcześniejsze rozpoznanie choroby, inwazyjne leczenie, wczesna rehabilitacja oraz opieka pielęgniarska warunkują powrót do zdrowia oraz do życia $\mathrm{w}$ środowisku domowym i zawodowym.

Cel. Celem niniejszej pracy jest rozpoznanie i analiza wybranych problemów wpływających na jakość życia pacjenta po przebytym zawale mięśnia sercowego.

Opis przypadku. Pacjent hospitalizowany z powodu silnego bólu w klatce piersiowej oraz uczucia drętwienia kończyn górnych. Wymaga obserwacji oraz pomocy przy poruszaniu się oraz wykonywaniu czynności dnia codziennego. Pacjent czuje lęk oraz strach o własne życie. 
Dyskusja. Tematem dyskusji są objawy, diagnostyka oraz czynniki ryzyka zawału mięśnia sercowego. Zostały poruszone tematy związane z wpływem choroby na aktywność zawodową pacjenta oraz jakość życia we wszystkich sferach.

Wyniki i wnioski. Zawał serca i jego konsekwencje znacząco zaburzają funkcjonowanie pacjenta we wszystkich obszarach jego życia. Istotnym elementem obok farmakoterapii, pielęgnacji i rehabilitacji mają działania edukacyjne ukierunkowane na pacjenta i jego rodzinę $\mathrm{w}$ celu zmiany stylu życia.

Słowa kluczowe: zawał mięśnia sercowego, jakość życia, aktywność zawodowa

\begin{abstract}
Introduction. Myocardial infarction is the most common cardiovascular disease. It is the necrosis of muscle cells in a particular area of the heart, caused by the coronary vessel occlusion, usually due to atherosclerotic plaque rapture. A patient after a heart attack must make necessary changes related to his current lifestyle. Early diagnosis of the disease, invasive treatment, early rehabilitation and nursing care determine recovery and the return to a normal life and work .
\end{abstract}

The aim. The aim of this study is to recognize selected problems affecting the quality of life of a patient after myocardial infarction.

A case report. The patient was hospitalized because of a severe chest pain and the feeling of numbness in the upper limbs. He requires observation and help with moving and performing everyday activities. The patient fears for his own life.

Discussion. The topic of the discussion are symptoms, diagnostics and risk factors for myocardial infarction. Issues related to the impact of the disease on the patient's professional activity and the quality of life in all spheres were raised.

Results and conclusions. Myocardial infarction and its consequences, significantly disturb the patient's performance in all areas of his life. I $n$ addition to pharmacotherapy, care and rehabilitation, educational activities aiming at the patient and his family in order to change their lifestyle are of key importance.

Key words: myocardial infarction, quality of life, professional activity 


\section{Wstęp}

Choroby układu sercowo-naczyniowego, ze względu na duże rozpowszechnienie, są ważnym problemem, który należy rozpatrywać nie tylko w wymiarze czysto medycznym, ale również społecznym i ekonomicznym. Schorzenia, których morfologicznym podłożem jest miażdżyca- choroba wieńcowa oraz jej skutki, głównie w postaci zawału mięśnia sercowego, są jedną $\mathrm{z}$ najczęstszych przyczyn hospitalizacji oraz czasowej lub trwałej niezdolności do pracy. Zawał mięśnia sercowego jest martwicą komórek mięśniowych określonego obszaru serca, która została wywołana zamknięciem światła naczynia wieńcowego, najczęściej w wyniku pęknięcia blaszki miażdżycowej. Dochodzi wówczas do przewężenia światła tętnicy wieńcowej lub jego całkowitego zamknięcia $[1,2,4]$.

Ze względu na ocenę patologiczną rozróżnia się dwa typy zawału serca: pełnościenny lub niepełnościenny (podwsierdziowy). Pierwszy z nich może obejmować całą grubość ściany komory; jest charakterystyczny przy zwężeniu jednej z gałęzi tętnic wieńcowych. Zawał niepełnościenny natomiast może lokalizować się podwsierdziowo oraz dotyczyć mięśni brodawkowatych. Jest charakterystyczny dla zwężenia wszystkich trzech gałęzi tętnic wieńcowych $[1,5]$.

Najczęściej przyczyną pęknięcia, bądź rozerwania blaszki miażdżycowej jest uszkodzenie śródbłonka, wywołane przez czynniki takie jak: siły ścinające prądu krwi, nadciśnienie tętnicze, hiperlipidemia lub ich kombinacja [1]. Do pozostałych przyczyn zawału serca zaliczamy:

- urazy lub zapalenia naczyń wieńcowych (kiła, choroba Takayasu, urazy mechaniczne, guzkowe zapalenie tętnic, rozwarstwienie aorty;

- embolia naczyń wieńcowych (infekcyjne zapalenie wsierdzia, embolia w czasie koronarografii, śluzak serca); 
- anomalie naczyń wieńcowych (odejście lewej tętnicy wieńcowej od tętnicy płucnej, tętniak tętnic wieńcowych, odejście lewej tętnicy wieńcowej od przedniej zatoki Valsalvy);

- dysproporcja w zaopatrzeniu mięśnia sercowego w tlen (niedomykalność zastawki i zwężenie ujścia aorty, zbyt długa hipotonia);

- przyczyny hematologiczne (wielopłytkowość, zespół wykrzepiania wewnątrznaczyniowego, czerwienica prawdziwa) [1].

Celem niniejszej pracy jest rozpoznanie i analiza wybranych problemów wpływających na jakość życia pacjenta po przebytym zawale mięśnia sercowego.

\section{Prezentacja przypadku}

Mężczyzna, 37 lat. Stan cywilny: żonaty, dorosła córka. Wykształcenie: średnie. Miejsce pracy: zakład produkcyjny. Choroby współistniejące: choroba niedokrwienna serca, nadciśnienie tętnicze.

Pacjent przyjęty do szpitala w godzinach porannych z powodu silnego bólu w klatce piersiowej oraz uczucia drętwienia kończyn górnych. Mężczyzna odczuwa silny niepokój oraz lęk. Po podaniu nitrogliceryny podjęzykowo ból nieznacznie ustąpił. Pilnie założono wkłucie dożylne i przekazano pacjenta do pracowni hemodynamicznej, gdzie przeprowadzono koronarografię (widoczne zmiany w tętnicach). Wykonano angioplastykę wieńcową $\mathrm{z}$ implantacją 3 stentów. Po zabiegu dolegliwości bólowe uległy zmniejszeniu, a pacjent został przewieziony na Oddział Intensywnej Opieki Kardiologicznej, celem wykonania podstawowych oraz specjalistycznych badań, monitorowania stanu ogólnego, zastosowania farmakoterapii, wdrożenia pielęgnacji. W badaniu echokardiograficznym wykazano nieswoiste zaburzenia okresu repolaryzacji komór oraz cechy przebytego zawału ściany dolnej serca. 
W tabeli 1 przedstawiono dane dotyczące pacjenta zebrane $\mathrm{w}$ ramach badania podmiotowego i przedmiotowego.

Tabela 1. Dane o pacjencie (krótka charakterystyka stanu pacjenta).

Imię i nazwisko (inicjały): XY

\begin{tabular}{|l|l} 
Wiek: 37 lat. & Stan cywilny: żonaty
\end{tabular}

Aktywność zawodowa: czynny

\begin{tabular}{l|l} 
zawodowo & Wykonywany zawód: stolarz
\end{tabular}

\begin{tabular}{|l|l|}
\hline Historia choroby & Stan ogólny \\
\hline $\begin{array}{l}\text { Rozpoznanie lekarskie: Zawał ściany } \\
\text { dolnej serca }\end{array}$ & Temperatura: $36,9{ }^{\circ} \mathrm{C}$ \\
\hline $\begin{array}{l}\text { Przyjmowane leki: Polocard, Zyllt, } \\
\text { Tritace, Simvasterol, }\end{array}$ & $\begin{array}{l}\text { Tętno: (liczba / napięcie / } \\
\text { rytm) 85/min., miarowe, } \\
\text { bardzo dobrze napięte }\end{array}$ \\
\hline Przebyte choroby: brak & Oddechy: 25/min. \\
\hline Pobyty w szpitalu: 2016r & $\begin{array}{l}\text { Ciśnienie tętnicze:157/95 } \\
\text { mmHg }\end{array}$ \\
\hline $\begin{array}{l}\text { Przebyte zabiegi operacyjne: usunięcie } \\
\text { przepukliny pępkowej }\end{array}$ & Masa ciała: 122 kg \\
\hline \multirow{2}{*}{ Przebyte urazy/wypadki: nie podaje } & Wzrost: $187 \mathrm{~cm}$ \\
\cline { 2 - 2 } & BMI: 34,86 \\
\cline { 2 - 2 } & WHR: brak oceny \\
\hline
\end{tabular}

Wywiad rodzinny

Członkowie rodziny: żona, córka

Ważne wydarzenia w rodzinie : brak

Choroby występujące w rodzinie: nadciśnienie tętnicze, cukrzyca

Hobby/zainteresowania: oglądanie wydarzeń sportowych

Formy spędzania czasu wolnego: odpoczynek w łóżku przed telewizorem, czytanie gazet 
Nałogi w rodzinie: palenie tytoniu

Błędy żywieniowe - nieregularność spożywanych posiłków, zbyt duże porcje, spożywanie produktów bogatych w tłuszcze oraz węglowodany, brak warzyw i owoców w diecie

Ograniczenia/przeciążenia psychicznego/fizyczne: nie podaje

Ograniczone kontakty/brak wsparcia społecznego: nie podaje

Wywiad środowiskowy
Miejsce zamieszkania: miasto
Rodzaj zajmowanego lokalu mieszkalnego: mieszkanie w kamienicy
Ilość zajmowanych pomieszczeń: 6
Ilość osób mieszkających wspólnie: 3
Stan higieniczno - sanitarny mieszkania: dobry
System pracy: 3- zmianowy
Ilość godzin spędzonych w pracy/szkole: 8 godzin dziennie
Zagrożenia zdrowia:
w domu: palenie papierosów
w pracy/szkole: palenie papierosów
Komunikacja: prawidłowa
Higiena osobista: dobra
Aktywność fizyczna: ograniczona
Wydalanie: prawidłowe
Odżywianie: nieprawidłowe
Sen/zasypianie: problemy z zasypianiem

Źródło: wynik badań własnych

W tabeli 2 zaprezentowano proces pielęgnowania pacjenta przyjętego do oddziału intensywnej opieki kardiologicznej. W planowaniu interwencji pielęgniarskich wykorzystano terminy zaczerpnięte $\quad \mathrm{z}$ ICNP® (Międzynarodowej Klasyfikacji Praktyki Pielęgniarskiej) - wersja 2017r. 
Tabela 2. Proces pielęgnowania pacjenta hospitalizowanego z powodu wystąpienia objawów zawału mięśnia sercowego $[3,6,8,9,12-15,17,18]$.

\begin{tabular}{|c|c|c|c|c|}
\hline $\begin{array}{l}\text { Problem } \\
\text { pielęgnacyjn } \\
\mathrm{y}\end{array}$ & $\begin{array}{l}\text { Cel } \\
\text { planowanych } \\
\text { działań } \\
\text { pielęgniarskic } \\
\text { h }\end{array}$ & $\begin{array}{l}\text { Planowane } \\
\text { interwencje } \\
\text { pielęgniarskie }\end{array}$ & $\begin{array}{l}\text { Uzasadnienie } \\
\text { planowanej } \\
\text { interwencji } \\
\text { pielęgniarskie } \\
\text { j }\end{array}$ & $\begin{array}{l}\text { Ocena } \\
\text { realizowanych } \\
\text { działań } \\
\text { pielęgniarskic } \\
\text { h }\end{array}$ \\
\hline $\begin{array}{l}\text { • Ból w } \\
\text { klatce } \\
\text { piersiowej } \\
\text { występujący } \\
\text { w przebiegu } \\
\text { zawału } \\
\text { mięśnia } \\
\text { sercowego. }\end{array}$ & $\begin{array}{l}\bullet \\
\text { Zniwelowanie } \\
\text { dolegliwości } \\
\text { bólowych. }\end{array}$ & $\begin{array}{l}\text { - Umieszczenie } \\
\text { pacjenta w sali } \\
\text { intensywnego } \\
\text { nadzoru } \\
\text { kariologicznego; } \\
\text { - Założenie } \\
\text { wkłucia do żyły } \\
\text { obwodowej; } \\
\text { - Ocena } \\
\text { nasilenia, } \\
\text { charakteru oraz } \\
\text { czasu trwania } \\
\text { bólu; } \\
\text { - Podanie leków } \\
\text { przeciwbólowyc } \\
\text { h zgodnie ze } \\
\text { zleceniem } \\
\text { lekarskim; } \\
\text { - Podanie leków } \\
\text { według zlecenia } \\
\text { lekarskiego; } \\
\text { • } \\
\text { Monitorowanie } \\
\text { tętna, ciśnienia } \\
\text { tętniczego krwi, } \\
\text { liczby } \\
\text { charakteru } \\
\text { oddechów, } \\
\text { saturacji, } \\
\text { ciśnienia } \\
\text { tętniczego krwi, } \\
\text { zabarwienia }\end{array}$ & $\begin{array}{l}\text { Stała kontrola } \\
\text { i ocena } \\
\text { dolegliwości } \\
\text { bólowych } \\
\text { minimalizują } \\
\text { ryzyko } \\
\text { wystąpienia } \\
\text { objawów } \\
\text { niepożądanyc } \\
\text { h w obrębie } \\
\text { układu } \\
\text { sercowo- } \\
\text { naczyniowego } \\
\text {. }\end{array}$ & $\begin{array}{l}\text { - Ból uległ } \\
\text { zmniejszeniu }\end{array}$ \\
\hline
\end{tabular}




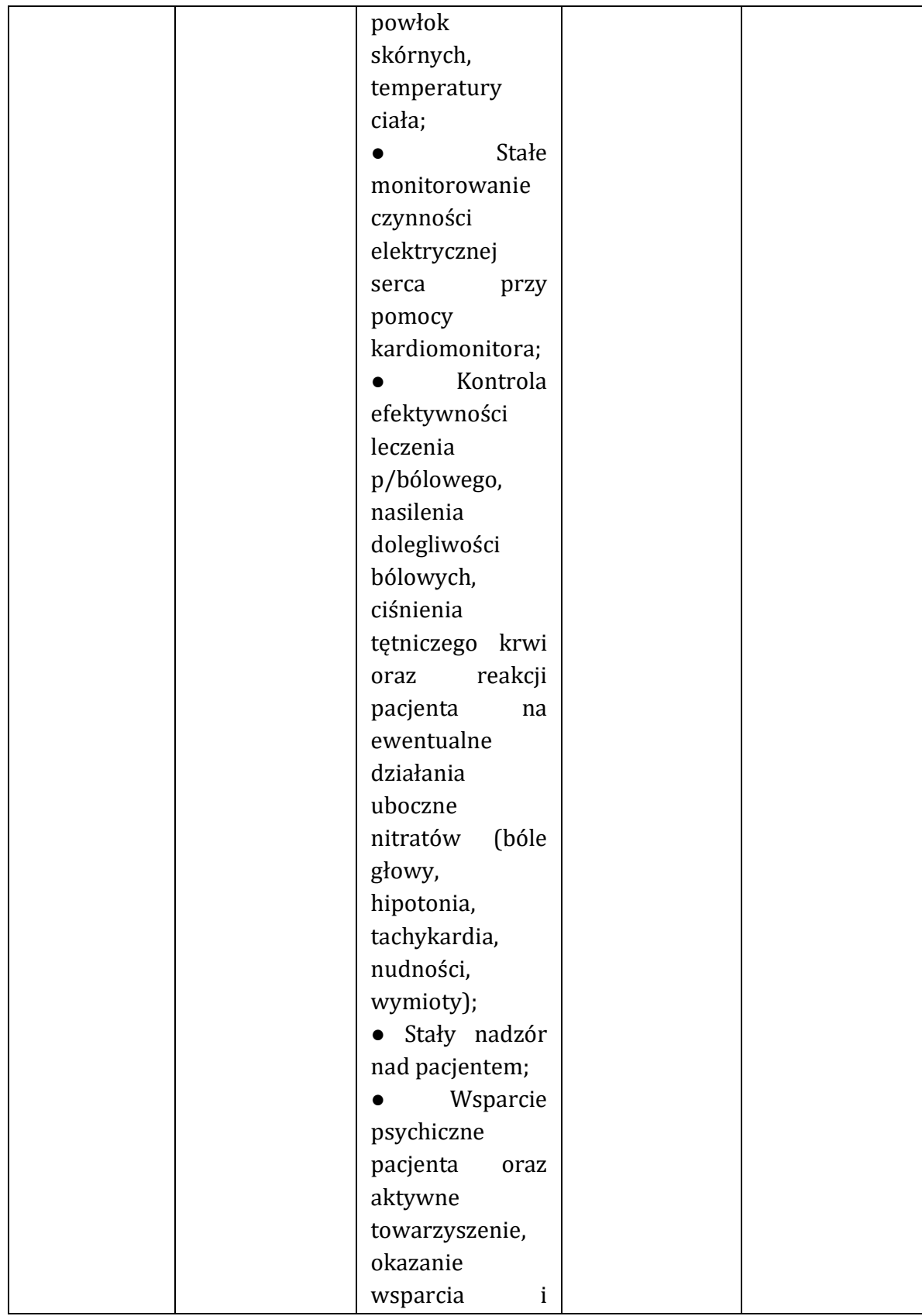




\begin{tabular}{|c|c|c|}
\hline & $\begin{array}{ll}\text { - zrozumienia; } \\
\text { • Zapewnienie } \\
\text { pacjentowi ciszy, } \\
\text { spokoju } \quad \text { oraz } \\
\text { warunków r do } \\
\text { wypoczynku. }\end{array}$ & \\
\hline $\begin{array}{l}\text { Diagnoza } \\
\text { negatywna } \\
(+\quad \text { kod } \\
\text { ICNP( })\end{array}$ & Interwencje & $\begin{array}{l}\text { Diagnoza } \\
\text { pozytywna }\end{array}$ \\
\hline $\begin{array}{l}\text { • Ból } \\
{[10023130]}\end{array}$ & $\begin{array}{l}\text { • Pozycjonowanie pacjenta } \\
\text { [10014761] } \\
\text { •Identyfikowanie postawy wobec } \\
\text { bólu [10009654] } \\
\text { • Ocenianie bólu [10026119] } \\
\text { - Monitorowanie bólu } \\
\text { [10038929] } \\
\text { - Ocenianie kontroli bólu } \\
\text { [10002710] } \\
\text { - Ocenianie psychologicznej } \\
\text { odpowiedzi na ból [10038964] } \\
\text { •Umieszczanie urządzenia do } \\
\text { dostępu żylnego [10034200] } \\
\text { - Administrowanie lekiem } \\
\text { przeciwbólowym [10023084] } \\
\text { - Administrowanie lekiem i } \\
\text { roztworem [10001804] } \\
\text { - Monitorowanie saturacji krwi } \\
\text { tlenem za pomocą pulsoksymetru } \\
\text { [10032047] } \\
\text { - Monitorowanie ciśnienia krwi } \\
\text { [10032052] } \\
\text { - Monitorowanie statusu } \\
\text { kardiologicznego [10034285] } \\
\text { • Monitorowanie statusu oddechu } \\
\text { [10012196] } \\
\text { • Ocenianie perfuzji tkanek } \\
\text { obwodowych [10042856] } \\
\text { • Ocenianie ryzyka negatywnej } \\
\text { interakcji na lek [10045940] }\end{array}$ & $\begin{array}{l}\text { - Zmniejszony } \\
\text { ból } \\
{[10027917]}\end{array}$ \\
\hline
\end{tabular}




\begin{tabular}{|l|l|l|}
\hline & $\bullet$ Ciągły nadzór [10005093] & \\
$\bullet$ Ocenianie zmęczenia & \\
{$[10026086]$} & & \\
$\bullet$ Zachęcanie do odpoczynku & \\
{$[10041415]$} & \\
$\bullet$ Wspieranie statusu & & \\
psychicznego [10019161] & & \\
\hline
\end{tabular}

\begin{tabular}{|c|c|c|c|c|}
\hline $\begin{array}{l}\text { Problem } \\
\text { pielęgnacyjny }\end{array}$ & $\begin{array}{l}\text { Cel } \\
\text { planowanych } \\
\text { działań } \\
\text { pielęgniarskich }\end{array}$ & $\begin{array}{l}\text { Planowane } \\
\text { interwencje } \\
\text { pielęgniarskie }\end{array}$ & $\begin{array}{l}\text { Uzasadnieni } \\
\text { e } \\
\text { planowanej } \\
\text { interwencji } \\
\text { pielęgniarski } \\
\text { ej }\end{array}$ & $\begin{array}{l}\text { Ocena } \\
\text { realizowany } \\
\text { ch działań } \\
\text { pielęgniarski } \\
\text { ch }\end{array}$ \\
\hline $\begin{array}{l}\text { - Duszność w } \\
\text { przebiegu } \\
\text { upośledzenia } \\
\text { czynności } \\
\text { serca }\end{array}$ & $\begin{array}{l}\text { - Ułatwienie } \\
\text { wymiany } \\
\text { gazowej } \\
\text { - Zmniejszenie } \\
\text { duszności. }\end{array}$ & $\begin{array}{l}\text { - Ocena stopnia } \\
\text { nasilenia } \\
\text { duszności; } \\
\text { •Ułożenie } \\
\text { pacjenta w } \\
\text { pozycji } \\
\text { wysokiej } \\
\text { •Podanie tlenu } \\
\text { według zlecenia } \\
\text { lekarskiego; } \\
\text { • } \\
\text { Monitorowanie } \\
\text { podstawowych } \\
\text { parametrów } \\
\text { życiowych; } \\
\text { • } \\
\text { Monitorowanie } \\
\text { saturacji- } \\
\text { podłączenie } \\
\text { pulsoksymetru; } \\
\text { - Umożliwienie } \\
\text { warunków do } \\
\text { odpoczynku, } \\
\text { unikanie } \\
\text { wysiłku; }\end{array}$ & $\begin{array}{l}\text { Stała } \\
\text { kontrola i } \\
\text { obserwacja } \\
\text { duszności } \\
\text { oraz stopnia } \\
\text { jej nasilenia } \\
\text { pomaga } \\
\text { wdrożyć } \\
\text { prawidłowe } \\
\text { działania } \\
\text { terapeutycz } \\
\text { ne mające na } \\
\text { celu } \\
\text { usprawniani } \\
\text { e procesu } \\
\text { rekonwalesc } \\
\text { encji } \\
\text { pacjenta, } \\
\text { zniesienie } \\
\text { niepokoju. }\end{array}$ & $\begin{array}{l}\text { - Duszność } \\
\text { ustąpiła. }\end{array}$ \\
\hline
\end{tabular}




\begin{tabular}{|c|c|c|}
\hline & $\begin{array}{ll}\bullet & \text { Stała } \\
\text { obecność } & \text { przy } \\
\text { pacjencie. } & \end{array}$ & \\
\hline $\begin{array}{l}\text { Diagnoza } \\
\text { negatywna } \quad(+ \\
\text { kod ICNP }()\end{array}$ & Interwencje & $\begin{array}{l}\text { Diagnoza } \\
\text { negatywna }\end{array}$ \\
\hline $\begin{array}{l}\text { • Duszność } \\
\text { [10029433] }\end{array}$ & $\begin{array}{l}\text { • Pozycjonowanie pacjenta } \\
\text { [10014761] } \\
\bullet \text { Monitorowanie oddychania } \\
\text { (wydolności) } \\
\text { [10012196] } \\
\text { - Monitorowanie statusu oddechu } \\
\text { [10012196] } \\
\text { - Monitorowanie saturacji krwi } \\
\text { tlenem za pomocą pulsoksymetru } \\
\text { [10032047] } \\
\text { - Monitorowanie ciśnienia krwi } \\
\text { [10032052] } \\
\text { - Monitorowanie statusu } \\
\text { kardiologicznego [10034285] } \\
\text { - Ocenianie perfuzji tkanek } \\
\text { obwodowych [10042856] } \\
\text {-Terapia tlenem [10039369] } \\
\text { •Ciągły nadzór [10005093] } \\
\text { - Zachęcanie do odpoczynku } \\
\text { [10041415] } \\
\text { - Ocenianie zmęczenia [10026086] }\end{array}$ & $\begin{array}{l}-\underset{c}{\text { bez }} \\
\text { duszności } \\
{[10029264]}\end{array}$ \\
\hline
\end{tabular}

\begin{tabular}{|c|c|c|c|c|}
\hline $\begin{array}{l}\text { Problem } \\
\text { pielęgnacyjn } \\
\text { y }\end{array}$ & $\begin{array}{l}\text { Cel } \\
\text { planowanych } \\
\text { działań } \\
\text { pielęgniarskic } \\
\text { h }\end{array}$ & $\begin{array}{l}\text { Planowane } \\
\text { interwencje } \\
\text { pielęgniarskie }\end{array}$ & $\begin{array}{l}\text { Uzasadnienie } \\
\text { planowanej } \\
\text { interwencji } \\
\text { pielęgniarskiej }\end{array}$ & $\begin{array}{l}\text { Ocena } \\
\text { realizowanyc } \\
\text { h działań } \\
\text { pielęgniarskic } \\
\text { h }\end{array}$ \\
\hline $\begin{array}{l}\text { - Niepokój } \\
\text { spowodowan } \\
\text { y } \\
\text { możliwością } \\
\text { wystąpienia } \\
\text { ponownego } \\
\text { incydentu }\end{array}$ & $\begin{array}{l}\bullet \\
\text { Zmniejszenie } \\
\text { niepokoju } \\
\text { pacjenta. }\end{array}$ & $\begin{array}{l}\text { Ocena } \\
\text { funkcjonowani } \\
\text { a pacjenta w } \\
\text { sferze } \\
\text { emocjonalnej, } \\
\text { poziomu } \\
\text { adaptacji do }\end{array}$ & $\begin{array}{l}\text { Niwelowanie } \\
\text { stresu pacjenta } \\
\text { poprzez } \\
\text { okazywanie } \\
\text { życzliwości, } \\
\text { zrozumienia, } \\
\text { wyrozumiałośc }\end{array}$ & $\begin{array}{l}\text { - Niepokój } \\
\text { pacjenta } \\
\text { zmniejszył } \\
\text { się. }\end{array}$ \\
\hline
\end{tabular}




\begin{tabular}{|c|c|c|c|c|}
\hline $\begin{array}{l}\text { choroby i ew. } \\
\text { śmierci. }\end{array}$ & & $\begin{array}{l}\text { warunków } \\
\text { szpitalnych, } \\
\text { stopnia } \\
\text { akceptacji } \\
\text { metod } \\
\text { diagnozowania, } \\
\text { leczenia i } \\
\text { pielęgnowania } \\
\text { oraz } \\
\text { nastawienia do } \\
\text { zespołu } \\
\text { terapeutyczneg } \\
\text { o i choroby; } \\
\text { - } \quad \text { Działania } \\
\text { mające na celu } \\
\text { ograniczenie } \\
\text { lęku, niepokoju } \\
\text { i negatywnych } \\
\text { skutków stresu } \\
\text { poprzez: } \\
\text { - zapewnienie } \\
\text { poczucia } \\
\text { bezpieczeństw } \\
\text { a; } \\
\text { - wysłuchanie } \\
\text { skarg i próśb; } \\
\text { - obecność przy } \\
\text { pacjencie; } \\
\text { - uspokojenie } \\
\text { pacjenta; } \\
\text { - wzbudzenie } \\
\text { zaufania; } \\
\text { - życzliwości } \\
\text { - prozumienia; } \\
\text { traktowanie } \\
\text { pacjenta i jego } \\
\text { rodziny; }\end{array}$ & $\begin{array}{l}\text { i, a także } \\
\text { zapewnienie } \\
\text { bezpieczeństwa } \\
\text { pozwolą } \\
\text { uniknąć } \\
\text { niepożądanych } \\
\text { efektów ze } \\
\text { strony układu } \\
\text { sercowo- } \\
\text { naczyniowego } \\
\text { spowodowanyc } \\
\text { h niepokojem. }\end{array}$ & \\
\hline Diagnoza & \multicolumn{2}{|l|}{ Interwencje } & & Diagnoza \\
\hline
\end{tabular}




\begin{tabular}{|c|c|c|}
\hline $\begin{array}{l}\text { negatywna (+ } \\
\operatorname{kod} I C N P ®)\end{array}$ & & pozytywna \\
\hline $\begin{array}{l}\text { - Niepokój } \\
\text { przed } \\
\text { śmiercią } \\
{[10041017]}\end{array}$ & 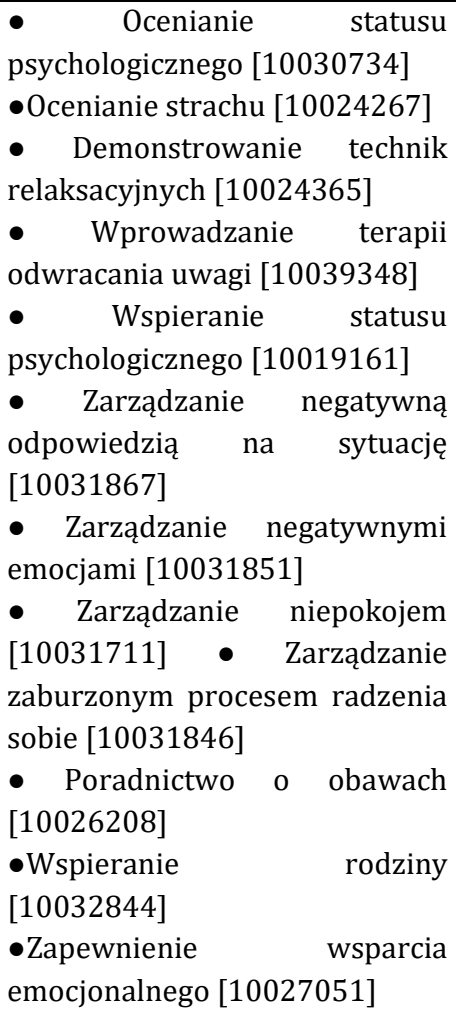 & $\begin{array}{l}\text { • } \\
\text { Zmniejszający } \\
\text { się niepokój } \\
{[10027858]}\end{array}$ \\
\hline
\end{tabular}

\begin{tabular}{|c|c|c|c|c|}
\hline $\begin{array}{l}\text { Problem } \\
\text { pielęgnacyjny }\end{array}$ & $\begin{array}{l}\text { Cel } \\
\text { planowanych } \\
\text { działań } \\
\text { pielęgniarskich }\end{array}$ & $\begin{array}{l}\text { Planowane } \\
\text { interwencje } \\
\text { pielęgniarski } \\
\text { e }\end{array}$ & $\begin{array}{l}\text { Uzasadnienie } \\
\text { planowanej } \\
\text { interwencji } \\
\text { pielęgniarskiej }\end{array}$ & $\begin{array}{l}\text { Ocena } \\
\text { realizowanyc } \\
\text { h działań } \\
\text { pielęgniarskic } \\
\text { h }\end{array}$ \\
\hline $\begin{array}{l}\text { - Deficyt } \\
\text { samoopieki } \\
\text { spowodowan } \\
\text { y aktualną } \\
\text { sytuacją } \\
\text { zdrowotna. }\end{array}$ & $\begin{array}{l}\text { - Zaspokojenie } \\
\text { potrzeb } \\
\text { pacjenta } \\
\text { zakresie } \\
\text { czynności } \\
\text { samoobsługow }\end{array}$ & $\begin{array}{l}\text { - Określenie } \\
\text { deficytów } \\
\text { pacjenta- } \\
\text { ocena } \\
\text { możliwości } \\
\text { pacjenta w }\end{array}$ & $\begin{array}{l}\text { Pomoc w } \\
\text { zaspokajaniu } \\
\text { potrzeb dnia } \\
\text { codziennego } \\
\text { pacjentowi } \\
\text { oraz }\end{array}$ & $\begin{array}{l}\text { - Deficyt } \\
\text { samoopieki } \\
\text { utrzymuje się } \\
\text {. }\end{array}$ \\
\hline
\end{tabular}




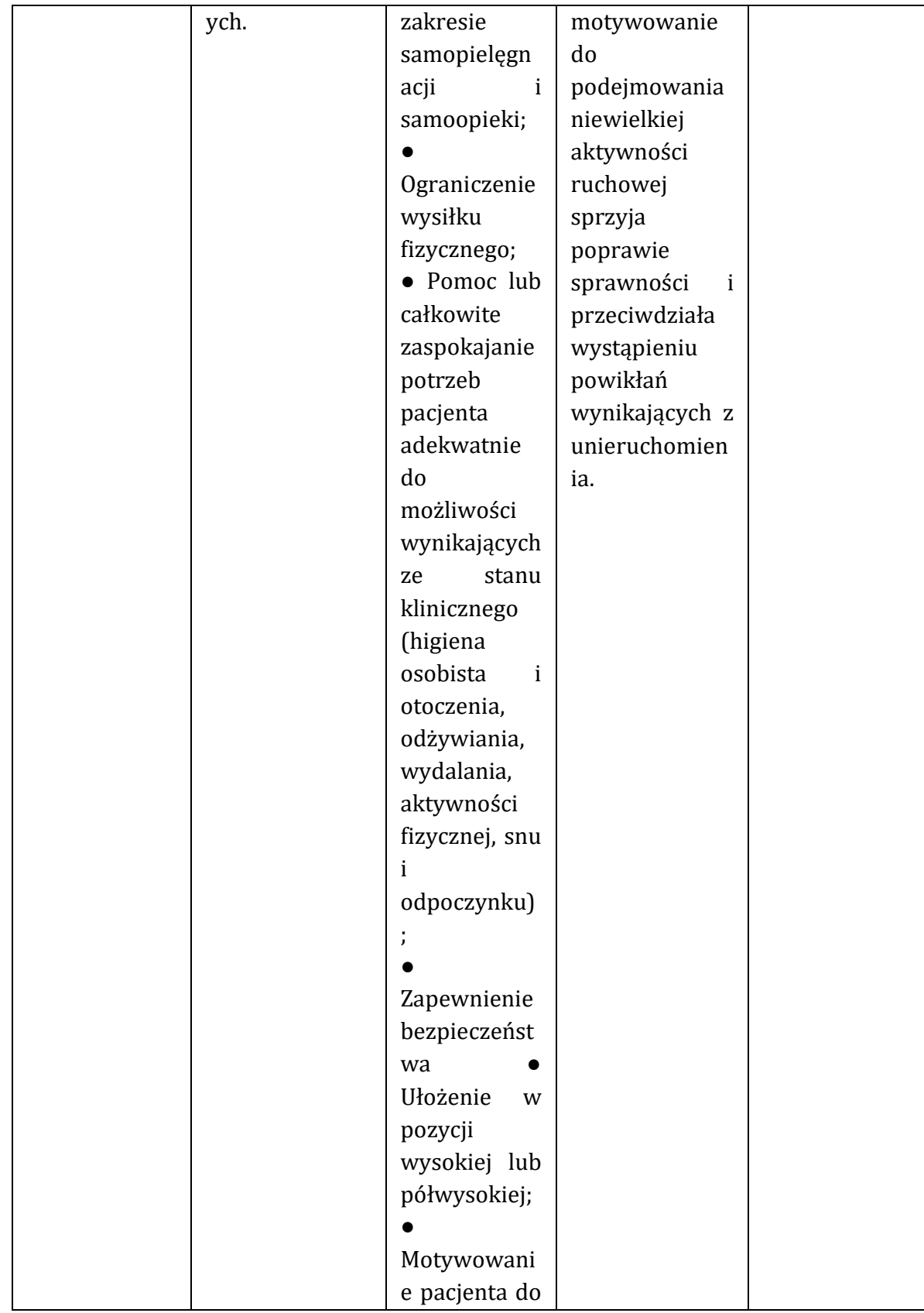




\begin{tabular}{|c|c|c|c|c|}
\hline & & $\begin{array}{l}\text { podejmowan } \\
\text { ia } \\
\text { aktywności } \\
\text { dostosowane } \\
\text { j do jego } \\
\text { wydolności; } \\
\text { - Stopniowe } \\
\text { zwiększanie } \\
\text { samodzielno } \\
\text { ści pacjenta. }\end{array}$ & & \\
\hline $\begin{array}{l}\text { Diagnoza } \\
\text { negatywna (+ } \\
\text { kod ICNP®) }\end{array}$ & \multicolumn{2}{|l|}{ Interwencje } & & $\begin{array}{l}\text { Diagnoza } \\
\text { pozytywna }\end{array}$ \\
\hline $\begin{array}{l}\text { • Deficyt } \\
\text { samoopieki } \\
{[10023410]}\end{array}$ & \multicolumn{2}{|c|}{ 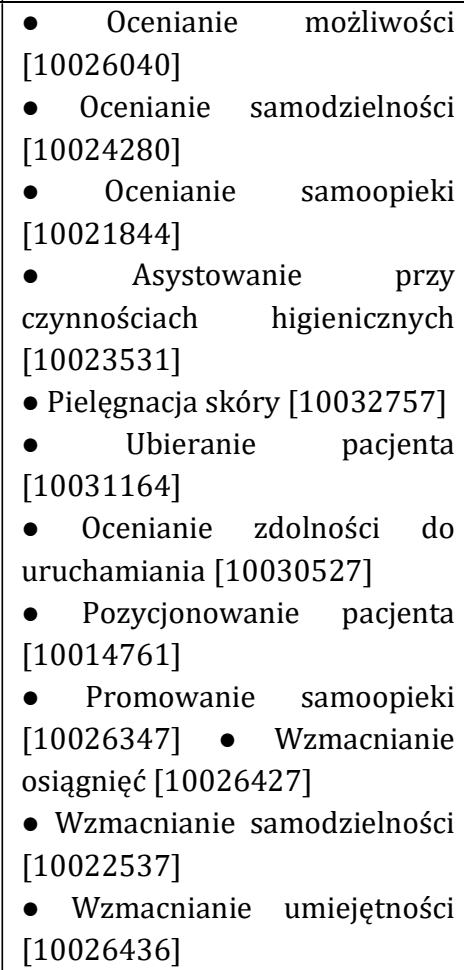 } & & $\begin{array}{l}\text { Deficyt } \\
\text { samoopieki } \\
\text { utrzymuje się }\end{array}$ \\
\hline $\begin{array}{l}\text { Problem } \\
\text { pielęgnacyj } \\
\text { ny }\end{array}$ & $\begin{array}{l}\text { Cel } \\
\text { planowanych } \\
\text { działań } \\
\text { pielęgniarskich }\end{array}$ & $\begin{array}{l}\text { Planowane } \\
\text { interwencje } \\
\text { pielęgniarskie }\end{array}$ & $\begin{array}{l}\text { Uzasadnienie } \\
\text { planowanej } \\
\text { interwencji } \\
\text { pielęgniarskiej }\end{array}$ & $\begin{array}{l}\text { Ocena } \\
\text { realizowan } \\
\text { ych działań } \\
\text { pielęgniars }\end{array}$ \\
\hline
\end{tabular}




\begin{tabular}{|c|c|c|c|c|}
\hline & & & & kich \\
\hline $\begin{array}{l}\text { - Ryzyko } \\
\text { wystąpieni } \\
\text { a krwotoku } \\
\text { z tętnicy } \\
\text { obwodowej } \\
\text { poddanej } \\
\text { nakłuciu w } \\
\text { ramach } \\
\text { zabiegu. }\end{array}$ & $\begin{array}{l}\text {-Niedopuszcze } \\
\text { nie do } \\
\text { wystąpienia } \\
\text { krwotoku. }\end{array}$ & $\begin{array}{l}\text { - Poinformowanie } \\
\text { pacjenta o: } \\
\text { - konieczności } \\
\text { pozostawania w } \\
\text { pozycji leżącej z } \\
\text { wyprostowaną } \\
\text { kończyną poddaną } \\
\text { interwencji; } \\
\text { - niepożądanych } \\
\text { skutkach wysiłku } \\
\text { lub zginania } \\
\text { kończyny, co może } \\
\text { skutkować } \\
\text { krwawieniem; } \\
\text { - stosowaniu } \\
\text { ucisku opatrunku } \\
\text { w czasie kichania } \\
\text { lub kaszlu. } \\
\text { - Ocena miejsca } \\
\text { punkcji pod kątem } \\
\text { krwawienia } \\
\text { (obecność świeżej } \\
\text { krwi na opatrunku, } \\
\text { wilgotność } \\
\text { opatrunku, ból, } \\
\text { tkliwość, obrzęk); } \\
\text { - Monitorowanie } \\
\text { podstawowych } \\
\text { parametrów } \\
\text { życiowych co 15, } \\
\text { 30 minut i co } 2 \\
\text { godziny, aż do } \\
\text { momentu } \\
\text { ustabilizowania się } \\
\text { stanu klinicznego } \\
\text { pacjenta; } \\
\text { • pobranie krwi do } \\
\text { badań na zlecenie } \\
\text { lekarza w celu }\end{array}$ & $\begin{array}{l}\text { Wdrożenie } \\
\text { planowanych } \\
\text { działań ma na } \\
\text { celu prewencję } \\
\text { wystąpienia } \\
\text { krwawienia w } \\
\text { miejscu } \\
\text { nakłucia. W } \\
\text { sytuacji } \\
\text { wystąpienia } \\
\text { krwawienia } \\
\text { działania } \\
\text { ograniczą } \\
\text { zasięg } \\
\text { krwawienia } \\
\text { oraz skutki } \\
\text { lokalne } \\
\text { następstwa } \\
\text { hemodynamicz } \\
\text { ne. }\end{array}$ & $\begin{array}{l}\text { • } \\
\text { Parametry } \\
\text { układu } \\
\text { krzepnięci } \\
\text { a } \\
\text { utrzymują } \\
\text { się na } \\
\text { prawidłow } \\
\text { ym poziomie. } \\
\text { • Krwotok } \\
\text { nie } \\
\text { wystąpił. }\end{array}$ \\
\hline
\end{tabular}




\begin{tabular}{|c|c|c|}
\hline & $\begin{array}{l}\text { monitorowania } \\
\text { układu } \\
\text { krzepnięcia; } \\
\text { - W sytuacji } \\
\text { pojawienia się } \\
\text { krwawienia lub } \\
\text { krwiaka ocena } \\
\text { stopnia jego } \\
\text { narastania, } \\
\text { poinformowanie } \\
\text { lekarza, usunięcie } \\
\text { opatrunku i } \\
\text { zastosowanie } \\
\text { ucisku na okolicę } \\
\text { poddaną } \\
\text { interwencji } \\
\text { zachowaniem } \\
\text { zasad aseptyki. }\end{array}$ & \\
\hline $\begin{array}{l}\text { Diagnoza } \\
\text { negatywna } \\
(+\quad \text { kod } \\
\text { ICNP@) }\end{array}$ & Interwencje & $\begin{array}{l}\text { Diagnoza } \\
\text { pozytywna }\end{array}$ \\
\hline $\begin{array}{l}\bullet \quad \text { Ryzyko } \\
\text { krwotoku } \\
\text { [10017268 } \\
\text { ] }\end{array}$ & $\begin{array}{l}\text { - Poradnictwo dla pacjenta } \\
\text { [10031062] } \\
\text { - Nauczanie pacjenta [10033126] } \\
\text { - Monitorowanie ciśnienia krwi } \\
\text { [10032052] } \\
\text { - Monitorowanie statusu } \\
\text { kardiologicznego [10034285] } \\
\text { - Monitorowanie statusu oddechu } \\
\text { [10012196] } \\
\text { - Ciągły nadzór [10005093] } \\
\text { - Ewaluacja gojenia się rany } \\
\text { [10007218] } \\
\text { - Identyfikowanie ryzyka krwotoku } \\
\text { [10009696] } \\
\text { - Nauczanie o reżimie terapii } \\
\text { [10024625] } \\
\text { - Ocenianie postawy wobec reżimu } \\
\text { terapii [10024205] }\end{array}$ & $\begin{array}{l}\bullet \quad \text { Bez } \\
\text { krwawieni } \\
\text { a } \\
{[10028806} \\
]\end{array}$ \\
\hline
\end{tabular}




\begin{tabular}{|l|l|l|l|}
\hline & $\bullet$ Ocenianie perfuzji tkankowej & \\
{$[10030775]$} & & \\
$\bullet$ Pobieranie próbki [10004588] & & \\
$\bullet$ Współdziałanie z lekarzem & \\
{$[10023565]$} & & \\
$\bullet$ Zachęcanie do odpoczynku & & \\
{$[10041415]$} & & \\
\hline
\end{tabular}

Źródło: wynik badań własnych

\section{Dyskusja}

Stres emocjonalny, wyczerpujący wysiłek fizyczny, choroby współistniejące to czynniki bezpośrednio wywołujące lub przyspieszające wystąpienie zawału serca. Większość pacjentów skarży się na długotrwały (powyżej 30 minut) ból w klatce piersiowej. Pacjenci charakteryzują go jako: tępy, rozpierający, rozrywający, ściskający, duszący, rwący, palący. Najczęściej ból zlokalizowany jest za mostkiem, po lewej stronie klatki piersiowej. Często promieniuje do lewego barku, ramienia, stawu łokciowego, dłoni, szyi, gardła, żuchwy lub pleców. Ból jest podobny do tego w dławicy stabilnej, jednakże jest znacznie silniejszy. Przy zawale dolnej ściany serca często jedynymi dolegliwościami są: ból brzucha, nudności, wymioty, złe samopoczucie. Nie u każdego w przypadku wystąpienia zawału serca pojawia się ból. Zamiast niego można również odczuwać duszność i uczucie ciężaru na klatce piersiowej. Zawałowi często towarzyszy także znaczne osłabienie, które może prowadzić do zasłabnięcia i utraty przytomności, zdenerwowanie, lęk i uczucie zbliżającej się śmierci [5].

Diagnostyka zawału mięśnia sercowego obejmuje wykonanie m.in. elektrokardiografii, echokardiografii [5]. Koronarografia - zabieg cewnikowania serca - ma na celu diagnostykę choroby wieńcowej. Podejmowany jest także $\mathrm{w}$ celach terapeutycznych. Koronarografia bezpośrednia selektywna polega na wstrzyknięciu środka cieniującego do światła każdej z obu tętnic wieńcowych. Dzięki temu otrzymuje się 
wyraźny obraz badanych naczyń, co pozwala na bardzo precyzyjną interpretację. Zabieg ten wykonuje się u osób z rozpoznaną chorobą niedokrwienną serca [5,7].

Dotychczasowy tryb życia pacjentów po zawale serca ulega znacznym zmianom. Chorzy muszą zaakceptować nową sytuację życiową, aby ich jakość życia była jak najbardziej zbliżona do tej przed chorobą. Wielu pacjentów z powodu stresu związanego z ryzykiem ponownego incydentu choroby świadomie rezygnuje z wielu obszarów aktywności życiowej. Pierwsze dni po wypisie ze szpitala mogą wiązać się $\mathrm{z}$ uczuciem niepokoju, obawą przed nawrotem dolegliwości bólowych, czy przed kolejnym zawałem. Ważne jest, aby w tym okresie chory otrzymał wsparcie ze strony osób bliskich. Pacjent szybciej powraca do zdrowia i sprawności, gdy ma poczucie własnej wartości, czuje się potrzebny. Wiara we własne siły sprzyja osiąganiu sukcesu i wyzwala dodatkową energię. Istotnym zaleceniem jest, aby w pierwszych dniach po powrocie do domu pacjent wypoczywał, lecz nie spędzał tego czasu leżąc w łóżku. Konieczne jest, aby podejmował niewielką aktywność fizyczną np.: spacery, przyrządzanie posiłków, lekkie prace domowe. Aktywność fizyczną należy stopniowo zwiększać [16].

Do najważniejszych konsekwencji zawału mięśnia sercowego należą: spadek wydolności fizycznej, zaburzenia w serze emocjonalnej i funkcjonowaniu społecznym chorego. W Polsce pracę zawodową po zawale mięśnia sercowego podejmuje zaledwie ok. 50-60\% osób. Osoby powracające do pracy $\mathrm{z}$ powodu zmienionej sprawności psychofizycznej muszą na nowo się do niej przystosować. Choroby serca i układu krążenia, w tym zawał, stanowią przyczynę około $30 \%$ przypadków niezdolności do pracy orzekanych w Polsce. Powoduje to poważne problemy społeczne, a także ekonomiczne, nie tylko w wymiarze indywidualnym, ale także w skali państwa [16]. Wśród pracujących osób po przebytym zawale mięśnia sercowego zauważa się mniejszą umieralność z powodu schorzeń układu krążenia oraz mniejszy odsetek ponownych incydentów kardiologicznych. Część 
osób, która przeszła zawał serca i ponownie podjęła aktywność zawodową musi zmienić zawód, stanowisko, a czasem nawet miejsce zatrudnienia. W przypadku tych osób zmieniają się zatem nie tylko ich możliwości wykonywania pracy spowodowane zawałem, ale również mogą zmienić się warunki i wymagania pracy. W sytuacji, kiedy problemy z przystosowaniem i stres z nim związany przedłużają się w czasie, może dojść do pogorszenia się stanu psychicznego, bądź fizycznego osoby po zawale serca, a w efekcie powoduje to niezdolność do pracy [16].

W profilaktyce powikłań czy kolejnych incydentów zagrażających życiu pacjenta w przebiegu chorób układu sercowonaczyniowego, konieczna jest eliminacja czynników ryzyka takich jak np. palenie tytoniu, otyłość, brak aktywności fizycznej [5,8]. Wiąże się to $\mathrm{z}$ koniecznością weryfikacji dotychczasowego stylu życia i wdrożenia zachowań prozdrowotnych. Z tego względu niezwykle istotna jest edukacja pacjentów, która ma na celu przygotowanie ich do samoopieki i samokontroli stanu zdrowia. Wskazówki edukacyjne należy przekazywać bezpośrednio choremu, ale także jego rodzinie zarówno w formie ustnej, jak i pisemnej. Mogą to być broszury, ulotki oraz pozycje z piśmiennictwa przeznaczonego dla pacjenta [16]

\section{Wnioski}

Zawał serca i jego konsekwencje znacząco zaburzają funkcjonowanie pacjenta we wszystkich obszarach jego życia. Istotnym elementem obok farmakoterapii, pielęgnacji i rehabilitacji, zmierzających do opanowania groźnych dla życia zaburzeń w funkcji układu sercowo-naczyniowego, mają działania edukacyjne ukierunkowane na pacjenta i jego rodzinę w celu zmiany stylu życia, a przyszłości umożliwiające podjęcie aktywności zawodowej. 


\section{Bibliografia/Bibliography:}

1. Mandecki T. Kardiologia. Wydawnictwo Lekarskie PZWL, Warszawa 2005, 306-316.

2. Kaszuba D., Nowicka A. Pielęgniarstwo kardiologiczne. Wydawnictwo Lekarskie PZWL, Warszawa 2011, 28-38, 133-138, 265-273.

3. Talarska D., Zozulińska-Ziółkiewicz D. Pielęgniarstwo internistyczne. Podręcznik dla studiów medycznych. Wydawnictwo Lekarskie PZWL, Warszawa 2011, 117-117.

4. Kubica J., Sinkiewicz W. Chory po zawale serca. Via Medica, Gdańsk 2008, 1-7, 33-35.

5. Braunwald E., Goldman L. Kardiologia. Wydawnictwo Medyczne Urban \&Partner, Wrocław 2007, 51-53, 93-99, 475-483.

6. Kilańska D. Międzynarodowa klasyfikacja praktyki pielęgniarskiej. ICNP® w praktyce pielęgniarskiej. Wydawnictwo Lekarskie PZWL, Warszawa 2015, 143-150.

7. Mroczkowska R., Serzysko B., Szkutnik M. Standardy opieki pielęgniarskiej w kardiologii inwazyjnej. Wydawnictwo Lekarskie PZWL, Warszawa 2016, 20-22.

8. Uchmanowicz I., Rosińczuk J. Badania naukowe w pielęgniarstwie i położnictwie. Tom 5. Wydawnictwo Continuo, Wrocław 2018, 337 348.

9. Uchmanowicz I., Rosińczuk J., Jankowska-Polańska B. Badania naukowe w pielęgniarstwie i położnictwie. Tom 4. Wydawnictwo Continuo, Wrocław 2017, 52-65 
10. Kózka M., Płaszewska-Żywko L. Procedury pielęgniarskie. Podręcznik dla studiów medycznych. Wydawnictwo Lekarskie PZWL, Warszawa 2009, 476-485.

11. Andres J., Kulig J. Opieka nad pacjentem leczonym chirurgicznie. Wydawnictwo Medyczne Urban\&Partner, Wrocław 2013, 50-56.

12. Grabowska H. Mapowanie pojęć ICNP® w procesie pielęgnowania pacjentów z przewlekłą niewydolnością serca. Część 1 - problemy somatyczne chorego. Problemy Pielęgniarstwa 2015; 23 (1): 104-109.

13. Grabowska H. Mapowanie pojęć ICNP® w procesie pielęgnowania pacjentów z przewlekłą niewydolnością serca. Część 2. Problemy Pielęgniarstwa 2015; 23 (1): 110-116.

14. Grabowska H., Grabowski W., Gaworska-Krzemińska A. Wykorzystanie ICNP® $\mathrm{w}$ opiece pielęgniarskiej nad pacjentem z nadciśnieniem tętniczym. Problemy Pielęgniarstwa 2014; 22 (1): 107-112.

15. Szlenk-Czyczerska E., Kędra E. Zadania pielęgniarki rodzinnej w opiece nad chorym z przewlekłą chorobą układu krążenia. Puls Uczelni 2016; (10) 3, 27-32.

16. Turczyn-Jabłońska K., Waszkowska M. Przystosowanie do pracy osób po zawale serca. Rozważania modelowe. Medycyna Pracy 2005; 56(1): 41-47.

17. Grabowska H., Grabowski W. Problemy pielęgnacyjne chorych w okresie pooperacyjnym w ujęciu Międzynarodowej Klasyfikacji Praktyki Pielęgniarskiej. Problemy Pielęgniarstwa 2014; 22 (3): 379-384.

18. http://www.icn.ch/ICNP-Browser-NEW.html. Data dostępu: 01.12.2018r.. 